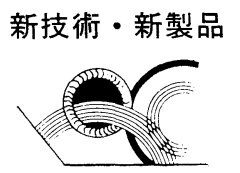

\title{
素材構成元素の蒸気圧差を利用した 表面改質技術の開発
}

1. は じめに

機器の高機能化, 長寿命化, 低コスト化等の要求から, 部品表面のみに機能層を形成させる表面改質技術が注目さ れている(1). その方法として古くは浸炭，溶射，めっきが あり, 最近では CVD(化学蒸着), PVD(物理蒸着), イ才 ン注入等の技術が開発されている。これらの表面改質法は 耐食性や耐摩耗性に優れた改質層を安価な素材表面に付着 ·形成させる技術である。しかしながら，改質層の豩離， 膜組成や膜厚の均一性, 製造コスト, 特に複雑形状への対 応などに問題があり，実用範囲が限定されている。

筆者らは，これらの問題を解決できるよらな新しい表面 改質技術として, 従来の発想とは全く異なり, 材料を構成 する元素の蒸気圧の差を利用し，素材自身の表面を改質す る技術を開発した。

\section{2. 開発の経 緯}

蒸気圧の大きく異なる元素から構成される素材を高温に 加熱すると, 蒸気圧の高い元素が表面から優先的に揮散 し，素材とは異なる組成をもった变質層を素材表面に形成 することができる，さらに，素材組成，熱処理条件(雲囲 気，温度，時間等）を制御することにより，表面に形成さ れる変質層を高機能化することも可能になると考えられ る.

この様な考えを $\mathrm{Fe}-\mathrm{Cr}-\mathrm{Mn}$ 系合金に適用した(2)。揮散 を促進するため真空䨌囲気下で Fe-Cr-Mn 合金を加熱処 理(揮散処理) し, 加熱前後の素材表面の EDX 分析值を比 較した。結果の一例を表 1 に示す．Fe および Cr に比較 し蒸気圧の高い Mnの濃度は, 揮散処理によって低下す ることがわかる。一方, 揮散処理後の $\mathrm{Fe}$ 濃度および $\mathrm{Cr}$ 濃度は素材濃度に比べ増加しているが，これは Mn 濃度

\footnotetext{
* (株)東芝

1) 総合研究所主任研究員 2) 総合研究所研究員 3) 総合研究所研究主務 4) 横浜金属部品工場部長

Development of Surface Modification by Vaporization; K. Tada, Y. Hisatsune, T. Fujiwara, M. Yamamoto, M. Kawai (Toshiba Corporation) 1991年 1 月 31 日受理
}

多田 薰1) 久恒善美光 藤原 鉄 雄3)

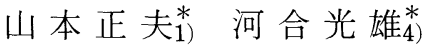

表 1 揮散処理前後の $\operatorname{EDX}$ 分析結果の一例.

\begin{tabular}{l|c|c|c}
\multicolumn{3}{c}{} & \multicolumn{2}{r}{ (wt\%) } \\
\hline \hline & $\mathrm{Mn}$ & $\mathrm{Cr}$ & $\mathrm{Fe}$ \\
\hline 揮散処理前(素材) & 20.1 & 20.6 & Bal. \\
\hline 揮散処理後(揮散条件 $\left.: 1100^{\circ} \mathrm{C}-1 \mathrm{~h}\right)$ & 14.8 & 24.0 & Bal. \\
\hline
\end{tabular}

表 2 揮散物質の ICP 発光分析結果の一例.

\begin{tabular}{c|c|c}
\multicolumn{2}{|c}{$(\mathrm{mg})$} \\
\hline \hline $\mathrm{Mn}$ & $\mathrm{Cr}$ & $\mathrm{Fe}$ \\
\hline 1.4 & 0.02 & 0.02 \\
\hline
\end{tabular}

の低下により相対的に増加したものと考えられる。なお, 揮散処理後の表面 $\mathrm{Mn}$ 濃度は雲囲気条件に依存するこ之 もわかった，表 2 に揮散物質を捕捉し，ICP 発光法によ り分析した結果の一例を示す． Fe および $\mathrm{Cr}$ 量に比べ Mn 量は 2 桁高く, 揮散処理時に Mn が素材から優先的に 揮散したことを示している.

$\mathrm{Fe}-\mathrm{Cr}-\mathrm{Mn}$ 系合金では図 1 亿示すように $\sigma$ 相の存在が知

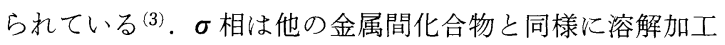
が困難であるが，上に述べたよらな揮散現象を利用して材 料表面にこの $\sigma$ 相を単相で形成することを試みた。すな わち，加工性が良好な Fe-Cr-Mn 系合金を素材としてこ れを高温に加熱し，表面から蒸気圧の高いMn を揮散さ せ, 表面のみを $\sigma$ 単相の組成に変動させることを試みた。

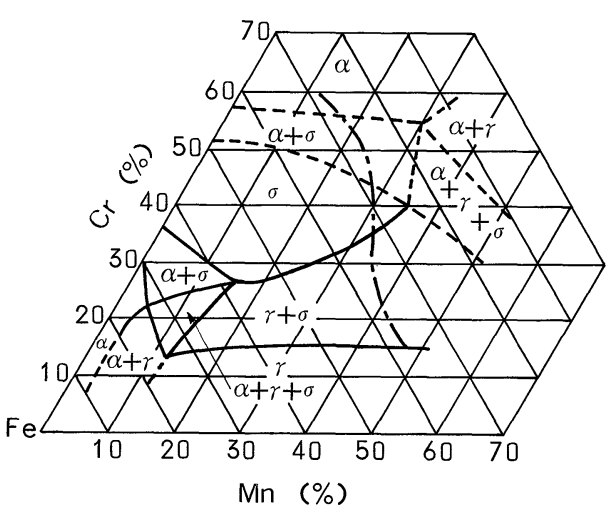

図 $1700^{\circ} \mathrm{C}$ にお 


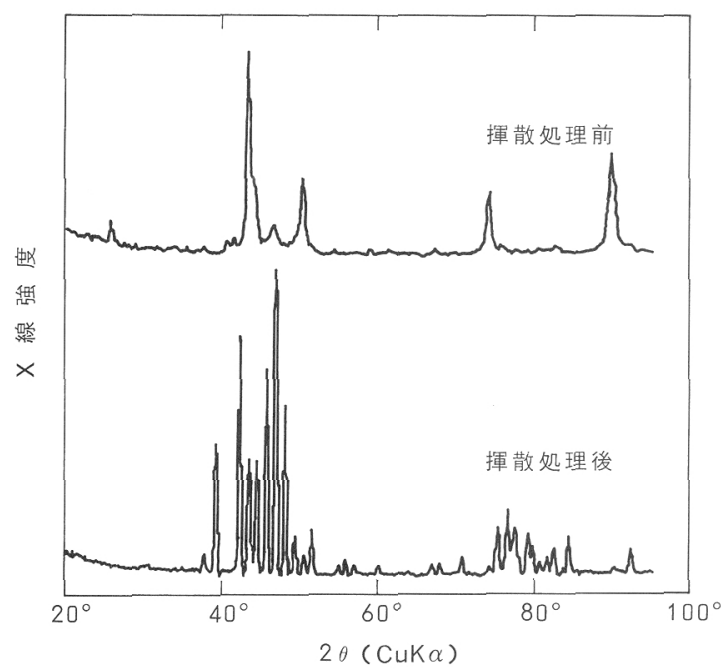

図 2 揮散処理前後の $\mathrm{X}$ 線回折パターン.

このため, 素材組成扣よび揮散処理条件の最適化を行っ た。図 2 亿組成吕最適化した Fe-Cr-Mn 系合金を $1100^{\circ} \mathrm{C}$ で揮散処理し，試料表面のX線回折を行った結果を素材 と比較して示す。 $\gamma$ 抢よび $\sigma$ の混合相からなる素材を揮散 処理することにより，素材表面を $\sigma$ 単相とすることが可 能であることが利かった。

\section{3. 改質層の特性}

揮散処理により $\sigma$ 相からなる表面改質層を形成させた 上記 Fe-Cr-Mn 系合金試料の断面写真在図 3 亿示古。李 た, 主要構成元素の EDX 分析結果拈よびビッカース硬度 測定結果表 3 亿示す。

$1100^{\circ} \mathrm{C}, 3$ 時間の揮散処理により，扮よそ $50 \mu \mathrm{m} の$ 厚さ の改質層が素材表面に均一比成されることがわかった。 本技術は素材自身の物理的性質を利用しているため, 表面 改質層の均質性が得られると考光られる。 未た, 改質層に は空隙などの欠陥は観察されず緻密であり, 揮散処理後も

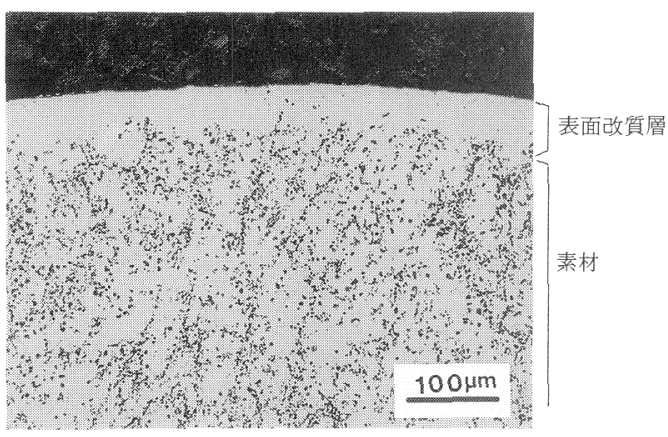

図 3 表面改質した Fe-Cr-Mn 合金の断面組織.
表 3 素材と表面改質層の EDX 分析和よび硬さ測定 結果.

\begin{tabular}{|c|c|c|c|c|c|}
\hline & \multicolumn{4}{|c|}{ 化学組成 (wt\%) } & \multirow{2}{*}{$\frac{\text { 硬 }}{(H v)}$} \\
\hline & $\mathrm{Mn}$ & $\mathrm{Cr}$ & $\mathrm{Ni}$ & $\mathrm{Fe}$ & \\
\hline 素 & 20.7 & 21.9 & 4.1 & Bal. & 355 \\
\hline 表面改質層 & 15.1 & 24.2 & 4.0 & Bal. & 940 \\
\hline
\end{tabular}

揮散条件 : $1100^{\circ} \mathrm{C}-3 \mathrm{~h}$

平滑な表面が得られることがわかった。一方，揮散処理に より $\mathrm{Mn}$ 濃度は素材の $20.7 \%$ から $15.1 \%$ に低下, 逆に $\mathrm{Cr}$ 濃度は増加寸るが，この組成変化に伴って引き起こされる 相変化は図 1 の平衡状態図から女予想されるものである。 表 3 に示したように $\sigma$ 相からなる改質層の硬さは Hv900 以上であり，本技術によ机ばHv350の素材を加熱処理す るだけで, 図 4 に示すよらに高速度鋼よりも硬く, 窒化層 之同等の硬さをもつ改質層で素材表面を覆らことができ る.

揮散処理温度および時間を変えた場合に形成される表面 改質層の厚さ，EDX分析值执よび硬さ至調べた。処理温 度の上昇や時間とともに改質層は厚くなるが, その組成お 上び硬さは処理温度や時間に依存せず, 揮散処理条件を制 御すれば任意の厚さの表面改質層が得られることがわから た。

スカッフ試験に上り求めた動摩擦係数とスカッフ值を各 種表面改質処理材と比較して図 5 に示寸. 図には参考のた

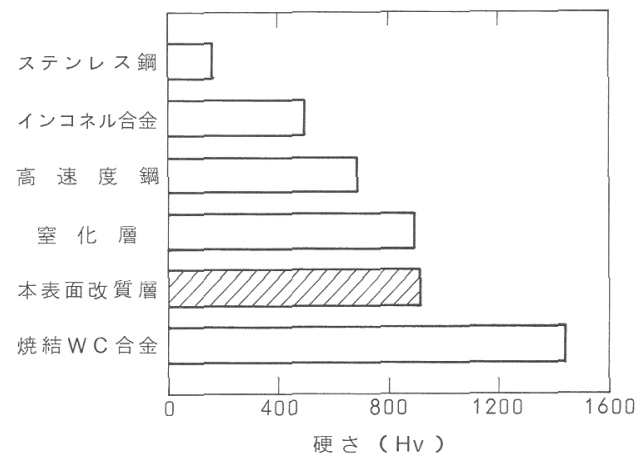

図 4 各種材料の硬さの比較.

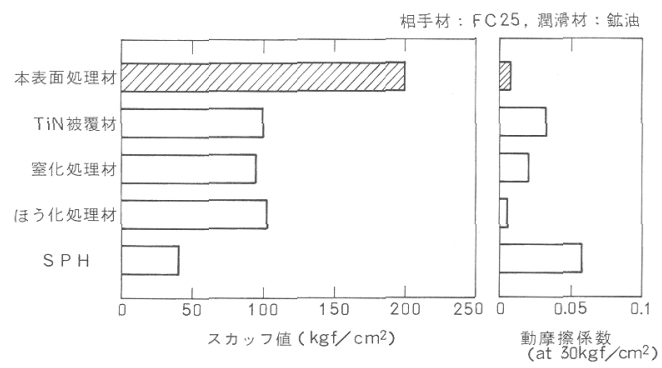

図 5 各種表面改質処理材の比較. 
め耐摩耗材料として FC25 と組み合わせ広く使用されてい る SPH の結果も示した。本技術を適用した表面改質層の 摩擦係数は $\mathrm{SPH}$ や $\mathrm{TiN}$ 被覆層, 窒化層の $1 / 2$ 以下と小さ く, 摺動特性に優れている。また, スカッフ值はSPHの 5 倍, $\mathrm{TiN}$ 被覆層や窒化層の 2 倍と耐焼付き性にも優れて いることがわかる.ささらに，本技術を適用した表面改質層 は素材との成分的な不連続性がないことから期待されるよ らに, 素材との密着性にも優れることがスクラッチ試験に よりわかった。

\section{4. ま め}

材料を構成する元素の蒸気圧の差を利用した新しい表面 改質技術を開発した。本技術によれば，複雑形状であって も, あらかじめ部品形状に加工した素材を加熱処理するだ 壮で，表面に均一に改質層を形成することができる．Fe-
$\mathrm{Cr}-\mathrm{Mn}$ 系合金では，Hv900 以上の高硬度な表面改質層を 数 $10 \mu \mathrm{m}$ の厚さ形成できることから, 耐摩耗性が必要と されるよらな各種摺動部品や金型，ノズルなどへの用途開 発を現在進めている.

なお，特許は特開昭63-241111他 7 件であり，平成 2 年 の注目発明に選定された。また，米国で 1 件成立 (Patent No. 4854978), EPC にも出願中である.

\section{文献}

（1）山科俊朗, 日野友明：日本金属学会会報, 27 (1988), 949.

（2）久恒善美, 藤原鉄雄, 多田 薰: 日本金属学会秋期大会 講演概要, (1990), 313.

(3) P. Schafmeister and R. Ergang: Arch. Eisen., 12 (193839), 507. 